\title{
A Different Spirit of
}

\section{Anzac: Illuminating}

Religion and War in

\section{Australian Archives}

Dr Michael Gladwin

- was pleased to be invited to offer this paper for a number of reasons: it is a chance to speak to a crowd of people who, like me, have a great love for books and reading; Lut more than that, who have a love of books that relate to theology, religious literature and church history; and even more than that, a crowd of people who probably enjoy hanging about in libraries and dusty archives as much as I do. So, in writing on the importance of theological libraries and theological librarians as they relate to my own sphere of writing on the history of Christianity, I feel that I am perhaps preaching to the choir.

Another similarity between theological librarians and historians (apart from woeful underfunding) came home to me during a 'light bulb' moment I had recently - that is, when I came across 'light bulb' jokes about librarians and historians. Forgive me for some levity; or for jokes that might be old hat for librarians:

Q. How many catalogue librarians does it take to change a light bulb?

A. I don't understand why we don't call it an 'Electric lamp, Incandescent' any more. And in any case, I just changed that light bulb a few years ago.

Q. How many young librarians does it take to change a light bulb?

A. LED light bulbs are a far more efficient technology with a lot of applications in brick-and-mortar information facilities, but it would be even better if we just digitized the collections and put them into accessible silos. 
The equivalent historians' light bulb joke runs something like this:

Q. How many historians does it take to change a light bulb?

A: There is a great deal of debate on this issue. Up until the mid- $20^{\text {th }}$ century, the accepted answer was 'one': and this Whiggish narrative underpinned a number of works that celebrated electrification and the march of progress in light bulb changing. Beginning in the 1960s, however, social historians increasingly rejected the 'Great Man' school and produced revisionist narratives that stressed the contributions of research assistants and custodial staff. This new consensus was challenged, in turn, by feminist historians, who criticized the social interpretation for marginalizing women, and who argued that light bulbs are actually changed by department secretaries. Since the 1980s, however, postmodernist scholars have deconstructed what they characterize as a repressive hegemonic discourse of light bulb changing, with its implicit binary opposition between 'light' and 'darkness,' and its phallocentric privileging of the bulb over the socket, which they see as colonialist, sexist, and racist. Finally, a new generation of neo-conservative historians have concluded that the light never needed changing in the first place, and have praised political leaders like Ronald Reagan and Margaret Thatcher for bringing back the old bulb. Clearly, much additional research remains to be done. ${ }^{\mathrm{i}}$

The common thread in these jokes, apart from their very questionable comedic value, is that both librarians and historians alike are constantly dealing with change: librarians with change in the larger landscape of technological changes, new professional practices and new systems, not least the modern fetish for digitization and online resources; and historians with historical change itself, and the neverending changes in theory and historical interpretation, as well as changing practices in research due to technological advances in digitization of sources and books, and changes in teaching with the delivery of lectures and tutorial via webinars and online. As you well know, these changes represent both challenges and opportunities, for historians and librarians alike.

As a religious historian working at St Mark's National Theological Centre in CSU's School of Theology and within the wider fields of Australian, military and British imperial history, my larger theme tonight is the enduring importance, in the midst of a period of rapid change, of theological libraries and librarians for the historian's task. Theologians may come at this from a different perspective, but I come at this theme from the perspective of a working religious historian on the Australian scene who also teaches the history of Christianity from undergraduate to doctoral level. In attempting to elucidate this theme, I'll draw on some of my own research, as well as research being 
done by other Australian religious historians. I also notice that the broader theme of the conference at which this paper is being presented is illuminations. My hope is that I can illuminate a perspective from the other side of the loans desk. Perhaps I can suggest that religious historians are more than just those pesky academics who take out way too many books for far too long. St Mark's librarian Susan Phillips, who deserves sainthood for her patience with people like me, knows what I'm talking about!

It has been said that if Australian religious historians don't write the history of Christianity in Australia, then no one else will. And if they don't, Christian historiography will be distorted by reductionist, simplistic caricatures that have tended to imbue some influential secular nationalist narratives in the past. But it's also true that if theological librarians don't source and curate the resources for Australians' historical and theological study, then no one else will. A striking example of this is the National Library of Australia (NLA), especially in holdings of secondary sources on religion, theology or spirituality. While I recognize that the library does an amazing job generally and has to be selective and focus on Australian material, there are just so many sources that are not in the library's holdings, even when written by Australian authors (my own recent book, a major historical study of all Anglican clergy in Australia before 1850, was not placed in the holdings of the NLA until I pointed this out to a senior archivist there). On my research day on Fridays I often have to shuttle back and forth between the NLA and my library, because just so many books are not in the NLA. In this sense, theological libraries and librarians are invaluable conduits for the vital work produced all over the world by theologians, Christian philosophers, and church historians.

My own published research has also attested to the crucial importance of theological libraries and librarians. My doctoral research, for example, examined the backgrounds, careers and influence of the 235 Anglican clergy who came to Australia before 1850. Sources were held in libraries and archives across Australia and the UK. At the heart of this $\mathrm{PhD}$ and the later book it became (Anglican Clergy in Australia, 1788-1850: Building a British World, Boydell and Royal Historical Society, Suffolk, 2015) is the finding that the 234 Anglican clergymen who served in Australia before 1850 played a far more important and expansive role in early Australian history than historians have recognized. The clergy have typically been seen only as founders of the Anglican Church and pioneers of education. But their contribution went much further and deeper in laying the foundations of Australian social, cultural and 
intellectual life. In fact, Anglican clergy, of whom 70 per cent were university educated, were among colonial Australia's front-rank public intellectuals, journalists, scientists, economists, classicists, humanitarian advocates, and pioneer pastoralists and agriculturalists. Clergy also founded literary journals and societies, libraries, museums, and patronised the arts. Several early clergymen served as magistrates in colonies where there were relatively few morally upright - or sober!elite candidates for the position.

This identification with the state, and its convict apparatus, including the lash, has provoked the anger of historians and novelists alike. Manning Clark, for example, characterized Anglican clergymen as 'moral policemen of the state', who advocated 'a religion for philistines, provincials and puritans'. ${ }^{1}$ This has given rise to the persistent historical myth of the 'flogging parson', in which parson-magistrates - notably the Reverend Samuel Marsden - have been cast as the pantomime villains of colonial Australia. Yet, as I demonstrate in the book, such interpretations are just not supported by the evidence. On the whole, clergy were advocates for convicts and the poor, and were intimately involved with their lives at a pastoral level. Finally, it is one of the delicious ironies of Australian history that Australia's wine and tobacco industries were founded by an Anglican clergyman with Methodist associations.

Another of my books, Captains of the Soul: A History of Australian Army Chaplains (2013), dealt with clergy - in this case the more than 2,000 Australian Army chaplains who have served Australian soldiers since 1788. Army chaplaincy represents, among other things: the biggest youth outreach in Australian religious history (among the 1st AIF and 2nd AIF): the biggest mobilization of religious leaders in Australian history; and the biggest ecumenical partnership in Australian history. This is in addition to the immense and immeasurable contribution of chaplains to the Australian Army, Australian soldiers and their families.

Both of these books demonstrated clergy as key figures in Australian colonial and military history. And both books relied heavily on the resources kept by theological libraries: sermons, letters, diaries, histories, memoirs, even the dreaded parish history! It should also be noted that clergy have always been among the most articulate and well-educated people in Australia, trained further by habits of reflection, selfexamination and pastoral awareness of the foibles and complexities of human nature. They have therefore provided a rich vein of sources for historians, not least me. It is also true that many Australian leaders and intellectuals have been sons or daughters of

${ }^{1}$ C. M. H. Clark, 'Faith', in P. Coleman (ed.), Australian Civilisation: A Symposium, Melbourne 1962, 78-9. 
the rectory or manse (here I am reminded of Friedrich Nietzsche's observation that modern German philosophers were by and large the grandsons of Lutheran clergy).

Along the way I have discovered some extraordinary people, and not least their wives and families, and uncovered stories of heroic sacrifice for the Gospel (dozens of chaplains, for example, lost their lives in the First and Second World Wars); stories of love and loss; and sometimes deeply poignant and moving stories such as that of Australian colonial clergyman, the Rev'd William Simpson, whom I got to know well through his detailed letters to supporters in England during the 1840s. He had ten children to feed and lived in a cramped four-bedroom house in country NSW. He had very little money and couldn't afford to educate a son who felt a vocation to the priesthood (his bishop provided a scholarship to England, fortunately). Yet his letters are marked by a humble and earnest desire to spread the Gospel of Christ and build the Anglican Church in pioneering colonial Australian condition. There is a tone of cheerful optimism despite hardships. I worked my way through these letters but was shocked one day upon reading a letter from a colleague that advised that Simpson was killed in the later 1840s after being thrown out of a coach. To my surprise and mild embarrassment I found myself quietly weeping in the archives after reading this letter-for this humble, hopeful clergyman I had got to know over several weeks.

Not surprisingly, given Australians' legendary capacity for humour in adversity, I also uncovered stories that have made me laugh out loud in libraries. While researching Captains of the Soul, I discovered that humour has always been an important pressure valve for relieving nervous tension, whether in moments of extreme stress or during the bizarre incidents that occur in war. During the hasty Allied retreat from Rommel's forces in North Africa during the Second World War, Baptist chaplain John Salter noted his fellow diggers referring to it as 'the Benghazi Handicap' !ii Anglican chaplain Francis Hulme-Moir was another muscular Christian noted for his imposing presence, booming bass voice and natural leadership qualities. ${ }^{\mathrm{iii}}$ He typified diggers' wry humour under pressure when, during the Japanese bombings of Darwin in 1942, he remarked to his Chaplain-General that:

[w] have a raid now and again, but the Japanese always comes off second best. The Chaplains here have asked me about a Retreat, not a strategic one but a spiritual one. ${ }^{\text {iv }}$

The joke was sometimes at the chaplain's expense, as one Second World War Australian soldier recounted: 
Part of a consignment of grog for the officers' mess went missing. There was hell to pay. At RC church parade the padre (himself an officer, of course) informed us that stealing was a sin - and, if his congregation included the offenders, the beer should be returned immediately. We didn't much fancy putting ourselves in, and the booze was hidden in a tricky spot, but my mate 'Blue' found the perfect solution: 'How about I tell the Father in confession? That way he's bound by the seal of the confessional and can't spill on us.' I said, 'Bloody ingenious, cobber.' And that's what I did.

'I stole the beer, Father.'

'You did? You must return it, now. Where is it?'

'Under the floorboards in your tent, Father.'

'Get it out of there?'

Some we drank, some we returned, and only three of us ever knew.

While on operation during the Vietnam War, Catholic chaplain John Tinkler forgot to affix small silver crosses to his bush shirt (denoting him as chaplain). A senior NCO on the helipad promptly offered to help:

Staff Sgt Jack Hill said, 'No problem Father' and drew them on my collars with a black Texta colour pen. I think everybody made some humorous friendly remark to me about it. It was a good idea and since then I have worn black crosses in the bush. It was not until a week later when I got a change of uniform that I realised the friendly remarks were because Jack had drawn a cross on one collar and a pitchfork on the other. ${ }^{\mathrm{vi}}$

Tinkler created more than one piece of chaplain folklore. 'I was ... playing footy in the army, he recalled:

and the umpire called me over and ... (he) went crook on me for something and then he said, 'By the way, you've got to stop your swearing because there's a priest playing today.' ${ }^{\text {vii }}$

Sadly my research also uncovered moral and personal failures, and an inability to live up to the ideals Christ set before his church. Fortunately, these were in the minority, but their damage was nevertheless profound and inexcusable. As we well know, clergy (and laypeople, for that matter) are not angels. In some cases they are not angels but Anglicans (to misquote Gregory the Great's famous phrase). Some of these stories border on the tragicomic. One Australian soldier of the First World War recounted the story of a chaplain who 
'had exhorted the boys not to be af raid of death, [promising] that he would be one of the first over the trench with them. And yet when the first shell drops near him he runs and some of the boys say he is still going, and not only that, but that he pinched a bicycle to get away on.' ${ }^{\text {'vii }}$

It is possible this was the origin of the well-worn phrase among Australian soldiers: 'shot through on the padre's bike'. In colonial Australia there were some spectacular failures: a horse-dealing clergyman who was only seen without a pipe in his mouth when in the pulpit; another clergyman who frequented pubs and whose housekeeper turned out to be more than a housekeeper; and several clergymen who went bankrupt through mad money-making schemes. The one I felt most sorry for was one who was described by his bishop as 'poor old heedless Dicken'. The young clergyman arrived in 1836 in Sydney after several months' voyage out from England; only days after his arrival he got drunk in the company of a Navy lieutenant, climbed out his window (even after the lieutenant had locked it), and ended up in George St Sydney in the early hours of the morning, speaking 'balderdash' in a cigar shop. The incident was splashed in the papers and the scandalized young clergyman was on a ship to India as soon as was practicable. . $^{\text {x }}$

II

All of these stories - of triumphs and failures, sinners and saints - need to be told. If history is about truth-telling, which I think it is, then the church needs it, as much as does any other aspect of Australian life, public or private. Taken together, these are important stories of influential leaders in church, society, and intellectual life that contribute to our national story and to our story as the church in Australia. In terms of the big picture, this work has sought to demonstrate the importance of religious actors, thinkers and leaders in Australian history. Not a few Australian historians have suffered from a secularist blind spot - or perhaps myopia - that has tended either to sidestep, or sideline, the deep religious streams that flow into the river of Australian cultural life. In many ways my own research has been an attempt to bring the Anglican clergy, the churches, and the religious and spiritual dimensions of Australian life back to where they belong, deep within the warp and weft of Australian history-only then can we have a full-orbed understanding of our national story.

Religious historians need to show where the church and religious experience fit into the larger picture of Australian life. Historians also needs to show the way in which the church has both shaped - and been shaped by-Australia's social, cultural, 
intellectual and political landscape. Church historians have seen this kind of project as a shift, since the 1960s, from the narrow institutional and theological focus of church history, to the much broader focus of modern religious history. This has brought religious historians in closer engagement with both professional historians in the academy and the larger public conversations about Australian history, culture and identity. My recent research has been trying to do this through examining the history of Christianity's role in Anzac Day commemoration. I have found that Christianity has remained integral to Anzac Day commemoration during its first century, whether directly involved in the creation of its distinctive ritual and forms, in leadership at its actual ceremonies, or in debating whether the day's 'proper' form and function should be solemn commemoration ( $\mathrm{a}$ ' $\mathrm{fast}$ ') or celebration (a 'feast'). ${ }^{\mathrm{x}}$

Australian Christian leaders have envisioned the civil religious dimensions of Anzac Day and the Anzac legend as both challenge and opportunity: on the one hand, a challenge to Australia's deeper Christian underpinnings and identity, especially given Anzac Day's hybrid religiosity, that has sometimes bordered on ancestor worship, pagan stoicism, or an inarticulate fumbling towards the transcendent. On the other hand, Australian Christians have sensed an opportunity to relocate points of cultural connection between the Anzac legend, the Christian faith and the spiritual aspirations of Australians who live in a secular world that is nevertheless haunted by the transcendent.

\section{III}

I mentioned earlier that theological libraries and librarians are invaluable conduits for the vital work produced all over the world by theologians, Christian philosophers and religious historians. This is all the more important as the need to understand religion moves higher up the agenda of cultural commentators and politicians in a new postCold War and post-911 world order. But your role as a key conduit of religious, historical and theological thinking is also becoming important for mainstream historians. One exciting development in the history profession in Australia is increasing recognition of the importance of religion generally-and Christianity specifically-in Australian history. I know, for example, of several front-rank historians in Australia, not all of whom are themselves committed believers, who are now incorporating religious and spiritual themes in their work - critically, of course, but also fairly and sympathetically. There is Geoffrey Blainey's recent history of Christianity; Penny Russell's stimulating work on colonial manners, including its religious dimensions, and her own nonconformist Christian heritage; Graeme 
Davison's efforts to ensure there were chapters on religion in the recently published, two-volume Cambridge History of Australia; my colleague Wayne Hudson's massively important new book, Australian Religious Thought, recently published by Monash University Press (on which Frank Bongiorno, Professor of History at ANU comments that the 'history of Australian religious thought receives here the sophisticated treatment that it richly deserves, in the hands of an author of phenomenal learning and intellectual range'). Perhaps most striking is the work of Alan Atkinson, whose third volume of his magisterial Europeans in Australia trilogy recently won $\$ 125,000$ worth of Australian book prizes. Atkinson, who might be described as the 'Manning Clark' of this generation of Australian historians, takes seriously the spiritual and religious impulses in Australia history. In a review of my recent book on Anglican clergy in Australia before 1850, in the Australian Journal of Politics and History, Atkinson had this to say:

History-writing in Australia has long featured a deep strain of bigotry, a belief that religious commitment involves a kind of false consciousness, a vacancy of mind not worth inquiring into. It has been a straightforward case of: "I do not understand it, and so it is not worth understanding". We are now edging towards a more open-minded, energetic acceptance of the importance of faith in human affairs, past and present. So we open up ... new arguments about subjectivity, emotion and community ... and new vistas on the Australian past. ${ }^{\mathrm{xi}}$

So, keep these injunctions in mind next time you complain about receiving the personal papers or library of a deceased or retired clergyperson - they are a potential goldmine for historians. And keep these thoughts in mind when you complain about the incessant orders for books that historians send your way.

In conclusion, I note that the theme this ANZTLA conference is 'Illuminate and Enlighten'. It seems an apt theme for a church historian who seeks to illuminate the past in the hope of enlightening our present. But that task is impossible without the herculean labours of theological librarians. And for this I offer my thanks and hopefully some encouragement in your important task. My hope is that, as you continue to wrestle with the consequences of constant change (just as we historians do), your work will be both illuminating and enlightening. 
${ }^{i}$ Accessed at http://historynewsnetwork.org/article/1690\#sthash.GhHOvllt.dpuf.

ii Michael Gladwin, Captains of the Soul: A History of Australian Army Chaplains. Sydney: Big Sky Publishing, 2013, p. 147.

iii Ibid.

iv Francis Hulme-Moir to Charles Riley, 27 April 1942, ‘Appointment of Chaplains', 1939-1942,

National Archives of Australia, MP508/1, 56/750/340.

${ }^{v}$ Gladwin, Captains of the Soul, p. 148.

vi Gladwin, Captains of the Soul, p. 225.

vii Ibid.

viii Ibid., p. 74.

ix Michael Gladwin. Anglican Clergy in Australia, 1788-1850: Building a British World, Woodbridge, Suffolk, Royal Historical Society and Boydell \& Brewer, 2015, pp. 188, 225.

“ Michael Gladwin. "Anzac Day's religious custodians." In Anzac Day Then and Now, edited by Tom Frame, Sydney: New South Press, 2016, 90-111. See also Michael Gladwin, ‘Anzac Day: Remembering for all the wrong reasons?', public lecture, St Mark's National Theological Centre, School of Theology, Canberra, 26 April 2016, https://www.youtube.com/watch?v=HJezOc_vdc4\&t=2688s).

${ }^{x i}$ Alan Atkinson, book review of Michael Gladwin, Anglican Clergy in Australia, 1788-1850: Building a British World, Woodbridge, Suffolk, Royal Historical Society and Boydell \& Brewer, 2015, in Australian Journal of Politics and History, vol. 61, no. 3, 2015, pp. 450-483.

Byline: Dr Michael Gladwin is Senior Lecturer in History at St Mark's National Theological Centre in the School of Theology, Charles Sturt University, Canberra. A graduate of the Australian National University and the University of Cambridge, his research has focused on the religious and cultural history of Australia and the British Empire, with a particular interest in the relationship between religion and war in Australian history. Michael is the author of Captains of the soul: a history of Australian Army chaplains (2013) and Anglican clergy in Australia, 1788-1850: building a British World (2015). He is currently editor of St Mark's Review, one of Australia's longest-running theological journals. 